Proceedings of the 10th International Ruminant Reproduction Symposium (IRRS 2018); Foz do Iguaçu, PR, Brazil, September 16th to 20th, 2018.

\title{
Evolution of fixed-time AI in dairy cattle in Brazil
}

\author{
Jose Luiz Moraes Vasconcelos ${ }^{1, *}$, Marcos Henrique Colombo Pereira ${ }^{1}$, Milo Charles Wiltbank ${ }^{2}$, \\ Thiago Guzela Guida ${ }^{1}$, Francisco Rebolo Lopes Jr. ${ }^{1}$, Carlos Patricio Sanches Jr. ${ }^{1}$, \\ Lucas Furtado dos Santos Pereira Barbosa ${ }^{1}$, Wedson Maria Costa Jr. ${ }^{1}$, Anderson Kloster Munhoz ${ }^{1}$ \\ ${ }^{1}$ Department of Animal Production, FMVZ-UNESP, Botucatu, SP, 18610-000, Brazil. \\ ${ }^{2}$ Department of Dairy Science, University of Wisconsin-Madison, Madison, WI, 53706, USA.
}

\begin{abstract}
Various programs have been used to synchronize ovulation of a fertile oocyte, accompanied by fixed-time artificial insemination (FTAI). These programs involve a series of hormonal treatments to achieve four physiologic outcomes: 1) synchronize an ovarian follicular wave; 2) optimize conditions for ovulatory follicle development; 3) synchronize corpus luteum (CL) regression; and 4) synchronize ovulation. This manuscript summarizes studies conducted in Brazil with lactating dairy cows that aimed to increase pregnancy rates to E2/P4-based programs.
\end{abstract}

Keywords: FTAI, pregnancy rates.

\section{Introduction}

Recent reviews have considered the history, physiological basis, and practical use of FTAI for reproductive management of dairy cattle (Baruselli et al., 2012; Binelli et al., 2014; Wiltbank and Pursley, 2014). This review will examine some specific published research manuscripts that were done with ample statistical power ( $>200$ cows/treatment) and, in our opinion, have been critical for the development of the programs that are in current use for FTAI in dairy cattle in Brazil.

Successful synchronization of ovulation and timed AI involves 4 essential physiological processes: 1) synchronize emergence of a new ovarian follicular wave; 2) optimize the environment for follicular wave development and selection of a single dominant follicle; 3) induce complete CL regression, resulting in low circulating progesterone ( $\mathrm{P} 4)$ near the time of $\mathrm{AI}$; and 4) induce synchronized ovulation, combined with an optimal schedule for FTAI. These programs use various hormones, including: gonadotropin releasing hormone $(\mathrm{GnRH})$, estradiol (E2) derivatives including estradiol benzoate (EB) and estradiol cypionate (ECP), intravaginal (P4) implants, and prostaglandin $\mathrm{F}_{2 \alpha}$ analogues (PGF). Achieving these physiologic goals using various combinations of hormones has generally resulted in two types of programs, one based primarily on GnRH (Pursley et al., 1995, 1997), used in the USA and several other countries, and E2/P4-based programs (Vasconcelos et al., 2011b; Wiltbank et al., 2011a), used in Brazil and elsewhere. Recent research has altered timing, dosages, and sequences of hormonal treatments, including merging these two types of programs striving to optimize the four principal processes of a synchronization program and thus improve fertility. This manuscript will focus on research done in Brazil to optimize FTAI programs in lactating dairy cattle. Information will be presented in the context of the four physiological processes essential for a successful FTAI program.

\section{Physiology I: Synchronization of emergence of a new ovarian follicular wave}

Understanding follicular waves was essential for initial development of FTAI protocols and their subsequent improvement (Thatcher and Santos, 2007; Wiltbank et al., 2011a; Wiltbank and Pursley, 2014). Synchronization of a new follicular wave near the beginning of a FTAI protocol has generally been done by two methods: 1) ovulation of the dominant follicle, usually with $\mathrm{GnRH}$; or 2) inhibition of gonadotropin secretion, usually with $\mathrm{EB}$, leading to regression of the current follicular wave and emergence of a new follicular wave. Neither of these treatments are completely efficient in lactating dairy cows, with only $50-65 \%$ of cows ovulating in response to $\mathrm{GnRH}$ treatment given at a random stage of the estrous cycle (Vasconcelos et al., 1999; Thatcher et al., 2002; Giordano et al., 2013; Wiltbank and Pursley, 2014) and 25 to $30 \%$ of dairy cows ovulating a persistent follicle, due to lack of regression of the previous follicular wave following EB treatment (Monteiro et al., 2015; Melo et al., 2016). Since it is likely that certain physiological processes, such as synchronized emergence of a new follicular wave, may be more critical in FTAI than during ET programs and therefore results of AI and ET have been compared in some of these studies.

An experiment (Vasconcelos et al., 2011b) was done to compare effects of two protocols for synchronization of ovulation (GnRH- vs. E2-based protocols) on $\mathrm{P} 4$ concentrations and fertility in lactating dairy cows subjected to either FTAI or fixed-time embryo transfer (FTET). A total of 883 lactating Holstein cows $(166.2 \pm 3.3$ days postpartum, yielding $36.8 \pm 0.34$ $\mathrm{kg}$ of milk/day) from eight commercial dairy farms were used. Within each farm, cows were randomly assigned to receive one of the two following treatments for synchronization of ovulation: 1) GnRH Group: day-10 P4 insert $(1.9 \mathrm{~g}$ of $\mathrm{P} 4$; CIDR $\mathbb{R})+\mathrm{GnRH}$, day-3 P4 withdrawal + PGF, day-2: ECP, day 0 FTAI or day 7 FTET $($ nFTAI $=180$; nFTET $=260)$; and 2) EB Group: Same as above, except EB on day-10 in lieu of GnRH 
$(\mathrm{nFTAI}=174 ;$ nFTET $=269)$. Circulating P4 on day-3 was greater in $\mathrm{GnRH}$ than EB treatment $(2.89 \pm 0.15$ vs. $2.29 \pm 0.15 \mathrm{ng} / \mathrm{ml} ; \mathrm{P}<0.01)$, but there were no effects of treatments on $\mathrm{P} 4$ on day $7(3.15 \pm 0.13$ vs. $3.03 \pm$ $0.14 \mathrm{ng} / \mathrm{ml} ; \mathrm{P}>0.10)$. Pregnancy rate at 60 days was higher for FTET compared to FTAI (37.6\% [199/529] vs. 26.5\% [94/354]; $\mathrm{P}<0.001)$. However, there were no effects of GnRH vs. EB on synchronized ovulation (87.0\% [383/440] vs. 85.3\% [378/443]), P/AI at 60 days $(27.2 \%[49 / 80]$ vs. $25.9 \%[45 / 174])$ or P/ET $(38.8 \%$ $[101 / 260]$ vs. $36.4 \% \quad[98 / 269])$, or when only synchronized cows are considered for P/AI at 60 days (35.3\% [55/156] vs. 33.8\% [50/148]) or P/ET (50.7\% [115/227] vs. 51.3\% [118/230]). Thus, either GnRH or EB could be used at the start of the protocol; although GnRH-treated cows had higher P4 during the protocol than those given EB, reproductive performance was similar.

Another study (Pereira et al., 2015) evaluated fertility in a FTAI protocol that compared EB versus EB $+\mathrm{GnRH}$ at the start of the protocol. For this study a GnRH treatment at the beginning of the protocol was added to a standard Brazilian protocol that was initiated with $\mathrm{EB}$ in order to evaluate whether ovulation of a dominant follicle in some cows could improve fertility due to greater synchronization of the follicular wave and greater circulating $\mathrm{P} 4$ during growth of the ovulatory follicle. Due to ovulation of a new follicle and consequently a CL, this study also evaluated using two PGF treatments at the end of the protocol to optimize CL regression (discussed in next section). Lactating Holstein cows $(n=1808)$ were randomly assigned during cool or hot seasons to receive FTAI (day 0) after one of three treatments: Control: CIDR $+2 \mathrm{mg}$ of $\mathrm{EB}$ on day-11, PGF on day-4, CIDR withdrawal $+1.0 \mathrm{mg}$ of ECP on day-2, and FTAI on day 0; 2PGF: Identical to the Control protocol, with addition of a second PGF treatment on day-2; and GnRH: Identical to the $2 \mathrm{PGF}$ protocol, with addition of $100 \mu \mathrm{g} \mathrm{GnRH}$ on day-11. Pregnancy diagnoses were done 32 and 60 days after FTAI.

Season had major effects on many reproductive measures, with more cool vs. hot season cows having a CL at PGF (62.9 vs. 56.2\%), expressing estrus (86.7 vs. $79.9 \%$ ), ovulating following the protocol (89.7 vs. $84.3 \%)$, becoming pregnant following the protocol (45.4 vs. $21.4 \%$ ), and having larger ovulatory follicle diameter at $\mathrm{AI}(15.7 v s .14 .8 \mathrm{~mm})$. The GnRH protocol increased percentage of cows with a CL (Control $=56.9 \%$; $2 \mathrm{PGF}$ $=55.8 \% ; \mathrm{GnRH}=70.5 \%)$ and circulating $\mathrm{P} 4$ concentrations on day-4 $(\mathrm{Control}=3.28 \pm 0.22 ; 2 \mathrm{PGF}=$ $3.35 \pm 0.22 ; \mathrm{GnRH}=3.70 \pm 0.21 \mathrm{ng} / \mathrm{ml}) . \mathrm{GnRH}$ also increased P/AI at 32 days (37.3\% [219/595]) and 60 days $(31 \%$ [179/595]) after TAI, compared to Control $(30.0 \% \quad[177 / 604]$ and $25.1 \%$ [145/604]) with intermediate results for the $2 \mathrm{PGF}$ protocol $(33.2 \%$ [196/609] and 28.0\% [164/609]). Positive effects of GnRH treatment on P/AI were only detected during the cool season $($ Control $=41.0 \%$; $2 \mathrm{PGF}=44.2 \%$; GnRH $=$ $50.9 \%$ ) but not during the hot season (Table 1). In addition, there was only a significant effect of GnRH in cows with low P4 $(<3 \mathrm{ng} / \mathrm{ml})$ at the start of the protocol, with no significant effect in cows that had high $\mathrm{P} 4$ at the outset. Further, there was an interaction for presence of $\mathrm{CL}$ at PGF with follicle diameter; cows with a CL at PGF had greater P/AI if they ovulated larger vs. smaller follicles near TAI.

In conclusion, combining GnRH with EB increased fertility, as compared to EB alone, when used at the start of an E2/P4-based protocol, particularly during the cool season and in cows with low P4 at the outset.

Table 1. Effects of various treatment protocols on pregnancies per AI (P/AI) during hot vs. cool seasons.

\begin{tabular}{|c|c|c|c|c|}
\hline \multirow{2}{*}{ Item* } & \multicolumn{3}{|c|}{ Protocol } & \multirow[b]{2}{*}{ P Value } \\
\hline & Control & 2PGF & GnRH & \\
\hline \multicolumn{5}{|c|}{$\mathrm{P} / \mathrm{AI} 32 \mathrm{~d}$ for all cows ${ }^{1}$} \\
\hline Cool & $41.0(116 / 283)^{b}$ & $44.2(125 / 283)^{\mathrm{y}}$ & $50.9(148 / 291)^{\mathrm{ax}}$ & 0.05 \\
\hline Hot & $19.0(61 / 321)$ & $21.8(71 / 326)$ & $23.4(71 / 304)$ & 0.40 \\
\hline P Value & $<0.01$ & $<0.01$ & $<0.01$ & \\
\hline Combined & $30.0(177 / 604)^{b}$ & $33.2(196 / 609)^{b, y}$ & $37.3(219 / 595)^{\mathrm{a}, \mathrm{x}}$ & 0.02 \\
\hline \multicolumn{5}{|c|}{ P/AI D60 for all cows ${ }^{1}$} \\
\hline Cool & $32.9(93 / 283)^{b}$ & $36.4(103 / 283)^{\mathrm{ab}}$ & $41.6(121 / 291)^{\mathrm{a}}$ & 0.09 \\
\hline Hot & $16.2(52 / 321)$ & $18.7(61 / 326)$ & $19.1(58 / 304)$ & 0.59 \\
\hline P Value & $<0.01$ & $<0.01$ & $<0.01$ & \\
\hline Combined & $25.1(145 / 604)^{b}$ & $28.0(164 / 609)^{\mathrm{a}, \mathrm{b}}$ & $31.0(179 / 595)^{\mathrm{a}}$ & 0.06 \\
\hline \multicolumn{5}{|c|}{ P/AI D32 for synchronized cows ${ }^{2}$} \\
\hline Cool & $46.6(110 / 236)^{b}$ & $49.0(120 / 245)^{\mathrm{ab}}$ & $55.7(142 / 255)^{\mathrm{a}}$ & 0.11 \\
\hline Hot & $22.5(52 / 231)$ & $26.0(60 / 231)$ & $27.4(61 / 223)$ & 0.47 \\
\hline P Value & $<0.01$ & $<0.01$ & $<0.01$ & \\
\hline Combined & $34.7(162 / 467)^{\mathrm{b}}$ & $37.8(180 / 476)^{\mathrm{y}}$ & $42.5(203 / 478)^{a^{x}}$ & 0.05 \\
\hline \multicolumn{5}{|c|}{ P/AI D60 for synchronized cows ${ }^{2}$} \\
\hline Cool & $37.7(89 / 236)^{\mathrm{y}}$ & $40.4(99 / 245)^{x y}$ & $45.5(116 / 255)^{x}$ & 0.20 \\
\hline Hot & $19.5(45 / 231)$ & $21.7(50 / 231)$ & $21.5(48 / 223)$ & 0.81 \\
\hline P Value & $<0.01$ & $<0.01$ & $<0.01$ & \\
\hline Combined & $28.7(134 / 467)^{\mathrm{y}}$ & $31.3(149 / 476)^{x y}$ & $34.3(164 / 478)^{\mathrm{x}}$ & 0.18 \\
\hline
\end{tabular}

*Least square means (n./n.); ${ }^{1}$ All inseminated cows; ${ }^{2}$ Includes only cows that ovulated to ECP (visible CL at day 7); $\mathrm{a}, \mathrm{b}$ Within a row $=\mathrm{P} \leq 0.05 ; \mathrm{x}, \mathrm{y}$ Within a row $=\mathrm{P}>0.05$ and $\mathrm{P} \leq 0.1$. From Pereira et al. (2015). 
Physiology II. Optimization of environment for follicular wave development and dominant follicle selection

In dairy cows, a variety of methods have been evaluated to increase fertility in synchronization of ovulation programs, including: increasing P4 concentration during ovulatory follicle development (Bisinotto et al., 2010; Martins et al., 2011; Wiltbank et al., 2011b), increasing length of proestrus (Peters and Pursley, 2003; Pereira et al., 2013b), reducing follicle age (Cerri et al., 2009; Santos et al., 2010), and supplementing estrogen (E2) during proestrus (Cerri et al., 2004; Brusveen et al., 2009; Souza et al., 2011). Enhanced steroid metabolism in lactating dairy cows (Sangsritavong et al., 2002; Vasconcelos et al., 2003) alters reproductive physiology in dairy cattle (Wiltbank et al., 2006), including changes in the preovulatory follicle and ovulated oocyte. For example, there is a decrease in fertility following ovulation of larger follicles, persistent follicles, or follicles that grew when P4 concentrations are low, apparently by reducing embryo quality 1 week after AI (Wiltbank et al., 2014). In addition, greater $\mathrm{P} 4$ concentrations during the TAI protocol and greater E2 concentrations near time of AI may optimize oviductal and uterine environments, thus improving fertility in high-producing dairy cows (Miller et al., 1977; Buhi, 2002).

Cows without a CL at initiation of FTAI protocols have lower circulating P4 concentrations during development of the preovulatory follicular wave and reduced P/AI after FTAI. An experiment (Pereira et al., 2017a) was designed to evaluate effects of increased circulating P4 during preovulatory follicle growth prior to FTAI or FTET, in lactating dairy cows without a CL. Lactating dairy cows with no $\mathrm{CL}$ and low circulating P4 $(\leq 1.0 \mathrm{ng} / \mathrm{ml})$ were assigned to a protocol using one or two intravaginal P4 implants (CIDRs) and subjected to FTAI or FTET. The low P4 cows for this experiment were identified on nine farms, of which four utilized FTAI ( $\mathrm{n}=326$ of 1,160 cows examined) and five utilized FTET ( $\mathrm{n}=445$ of 1,396). All cows were synchronized by insertion of one or two P4 implant(s) (CIDR[s]) at start of protocol (day-11) and simultaneous treatment with $2 \mathrm{mg}$ of EB. Seven days later, cows were treated with PGF (day-4) and $2 \mathrm{~d}$ later treated with $1.0 \mathrm{mg}$ ECP and CIDR(s) were removed (day-2). Cows received FTAI on day 0 or FTET on day 7 . Cows were also randomly assigned to receive either one or two CIDRs from day-11 until day-2 (1CIDR vs. 2CIDR). The 2CIDR treatment increased circulating $\mathrm{P} 4$ at day-4 $(2.18 \pm 0.24 v s .1 .77 \pm 0.23 \mathrm{ng} / \mathrm{ml})$ but had no effect on ovulation at end of protocol $(83.6 v s .82 .6 \%)$ or ovulatory follicle diameter $(15.6 \pm 0.3 v s .15 .3 \pm 0.3 \mathrm{~mm})$. If only cows that ovulated to the protocol were included, 1CIDR tended to have lower P/AI than 2CIDR at 32 days (42.8vs. 52.6\%; $\mathrm{P}=0.10)$ and 60 days $(37.7 v s$. $48.1 \% ; \mathrm{P}=0.08)$, with no effect on pregnancy loss. There was an interaction $(\mathrm{P}=0.05)$ between ovulatory follicle diameter and CIDR treatment (Fig. 1) on P/AI (day 60). In cows ovulating larger follicles $\searrow(14 \mathrm{~mm})$, 2CIDR treatment increased P/AI compared to 1CIDR (53.3 vs. 34.9\%; $\mathrm{P}=0.02$ ) but not in cows ovulating small follicles $(<14 \mathrm{~mm})$. There was no effect of treatment on $\mathrm{P} / \mathrm{ET}$ at 32 days $(30.0$ vs. $32.0 \%)$ or 60 days (24.7 vs. $25.6 \%)$. Thus, these results add evidence to the concept that increased circulating P4 concentrations during preovulatory follicle development may improve P/AI, most likely due to improved oocyte quality in cows that ovulate larger follicles, since there was improved fertility only in cows ovulating larger follicles, with no significant effect of preovulatory $\mathrm{P} 4$ concentrations in cows that ovulated smaller follicles or that received FTET.

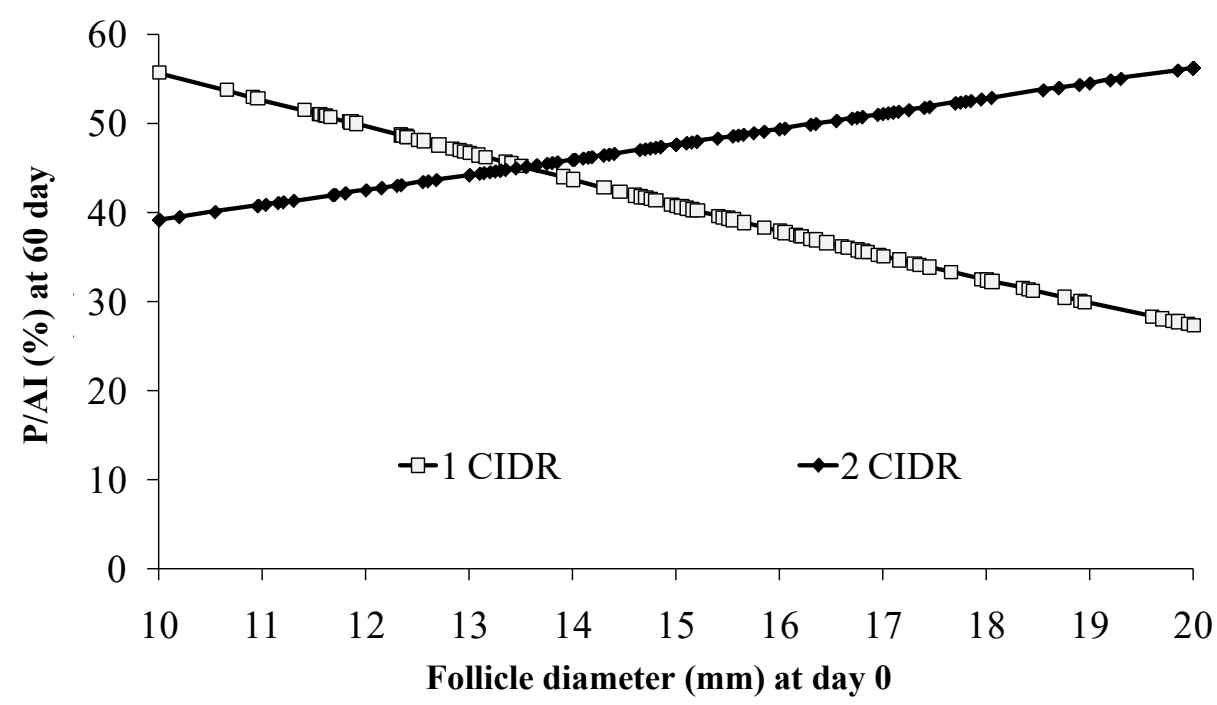

Figure 1. Effects of follicle diameter at time of AI (day 0) on P/AI at day 60 pregnancy diagnosis in dairy cows that ovulated to the protocol ( $\mathrm{CL}$ on day 7$)$. There was an interaction $(\mathrm{P}=0.05)$ between treatment and follicle diameter on $\mathrm{P} / \mathrm{AI}$ at day 60 apparently due to P/AI decreasing in cows with larger follicles in cows with only 1 CIDR but increasing with follicle size in cows with 2 CIDRs. From Pereira et al. (2017a). 
Length of an E2/P4 FTAI protocol has also been evaluated (Pereira et al., 2014). Lactating Holstein cows $(n=759)$ were given a CIDR for either 8 or $9 \mathrm{~d}$ with $2 \mathrm{mg}$ EB treatment at beginning, PGF 2 days before CIDR removal, and CIDR removal with $1 \mathrm{mg}$ ECP at 2 days before FTAI. Cows were considered to have their estrous cycle synchronized in response to the protocol by the absence of a CL at AI (D0) and presence of a CL on day 7. Pregnancy diagnoses were performed at 32 and 60 days. Ovulatory follicle diameter at FTAI did not differ, although the $9 \mathrm{~d}$ program tended $(\mathrm{P}=0.06)$ to have greater $\mathrm{P} 4$ on day 7 in synchronized cows $(3.14 \pm 0.18 \mathrm{ng} / \mathrm{ml})$ than the 8 days program $(3.05 \pm$ $0.18 \mathrm{ng} / \mathrm{ml})$. Although $\mathrm{P} / \mathrm{AI}$ at 32 days ( 8 days $=45 \%$ $[175 / 385]$ vs. 9 days $=43.9 \%[166 / 374] ; \mathrm{P}=0.77)$ and at 60 days $(8$ days $=38.1 \%$ [150/385] vs. 9 days $=$ $40.4 \%$ [154/374]; $\mathrm{P}=0.52)$ was not different, the 9 days program had lower $(\mathrm{P}=0.04)$ pregnancy losses $(7.6 \%[12 / 166])$ than the 8 days program $(14.7 \%$
[25/175]). Cows in the 9 days program were more likely $(\mathrm{P}<0.01)$ to be in estrus $(72.0 \%[269 / 374])$ than those in the 8 days program (62\% [240/385]). Expression of estrus improved estrous cycle synchronization (97.4\% [489/501] vs. 81\% [202/248]; $\mathrm{P}<0.01), \mathrm{P} 4$ concentrations at day $7(3.22 \pm 0.16 v s$. $2.77 \pm 0.17 \mathrm{ng} / \mathrm{ml} ; \mathrm{P}<0.01), \mathrm{P} / \mathrm{AI}$ at 32 days $(51.2 \%$ [252/489] vs. 39.4\% [81/202]; $\mathrm{P}<0.01)$ and at 60 days (46.3\% [230/489] vs. 31.1\% [66/202]; P < 0.01), and it decreased pregnancy loss $(9.3 \%$ [22/252] vs. $19.8 \%$ $[15 / 81] ; \mathrm{P}<0.01)$, compared to cows not detected in estrus. Those not detected in estrus with small $(<11 \mathrm{~mm})$ or large follicles $(>17 \mathrm{~mm})$ had greater pregnancy loss $(\mathrm{P}=0.01)$; however, in cows detected in estrus, there was no effect $(\mathrm{P}=0.97)$ of follicle diameter on pregnancy loss (Fig. 2). In conclusion, increasing the length of the protocol for FTAI increased the percentage of cows detected in estrus and reduced pregnancy losses.

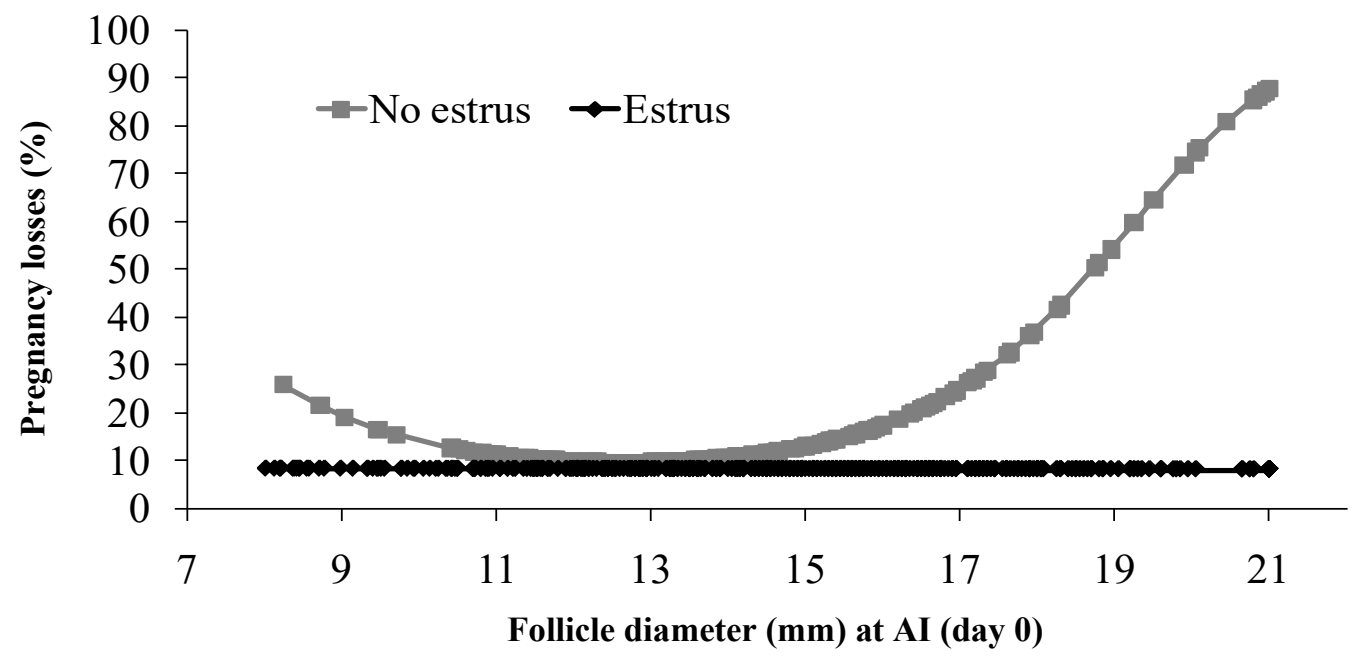

Figure 2. Effects of expression of estrus and follicle diameter at AI (day 0) on pregnancy losses between 32 and 60 days in synchronized dairy cows. No estrus $\mathrm{P}=0.01$, estrus $\mathrm{P}=0.97$. From Pereira et al. (2014).

A final experiment was done to compare two protocols that increase P4 during preovulatory follicle development (Pereira et al., 2017b). One treatment utilized two intravaginal P4 implants (CIDR), whereas the other utilized GnRH at start of the protocol. Lactating Holstein cows that had been diagnosed as non-pregnant were randomly assigned to receive FTAI following one of two treatments $(\mathrm{n}=1,638$ breedings): GnRH - CIDR $+2 \mathrm{mg}$ EB $+100 \mu \mathrm{g}$ GnRH on day-11, PGF on day-4, CIDR withdrawal + ECP + PGF on day2 , and TAI on day 0 ; or 2 CIDR - Two CIDR + EB D11 , one CIDR withdrawn + PGF on day-4, second CIDR withdrawn + ECP + PGF on day-2, and FTAI on day 0 . There was no effect of treatments $(\mathrm{P}>0.10)$ on $\mathrm{P} / \mathrm{AI}$ or pregnancy loss. Various physiological measurements associated with greater fertility were reduced $(\mathrm{P}<0.01)$ in cows with an elevated body temperature (compared to those without), including: cows with CL at PGF (decreased $7.9 \%$ ), ovulatory follicle diameter (decreased $0.51 \mathrm{~mm}$ ), expression of estrus (decreased 5.1\%), and ovulation near FTAI (decreased 2.8\%). There were a greater proportion of cows $(30.2 \%$; $\mathrm{P}<0.01)$ with a $\mathrm{CL}$ at $\mathrm{PGF}$ in the GnRH (74.1\% [570/763]) than 2CIDR treatment (56.9\% [434/763]). However, circulating P4 was greater $(\mathrm{P}=0.05)$ at $\mathrm{PGF}$ treatment $($ day-4) for cows treated with 2 CIDR $(4.26 \pm 0.13 \mathrm{ng} / \mathrm{ml})$ than $\mathrm{GnRH}$ $(3.99 \pm 0.14 \mathrm{ng} / \mathrm{ml})$. Thus, these two protocols yield similar fertility (Table 2), although that was likely due to somewhat different physiological alterations. Exogenous GnRH increased the proportion of cows with a CL at PGF; however, the 2CIDR protocol increased circulating $\mathrm{P} 4$ under all circumstances.

In conclusion, optimizing the length of the protocol and increasing circulating P4 during the protocol are strategies currently used to increase fertility during FTAI protocols in dairy cattle in Brazil. Similarly, with high-yielding dairy cattle in other countries, increasing P4 during the FTAI protocol can increase fertility (Wiltbank et al., 2014). 
Table 2. Effects of two different protocols and rectal temperature on ovulation to ECP, P/AI at the 32 or 60 days pregnancy diagnosis, and pregnancy loss from 32 to 60 days. The two protocols were both designed to increase circulating P4 during the protocol using either GnRH at beginning (GnRH) or 2 CIDRs rather than only 1 CIDR during the protocol (2CIDR).

\begin{tabular}{|c|c|c|c|c|c|}
\hline \multirow[b]{2}{*}{ Item* } & \multicolumn{2}{|c|}{ Rectal temperature $\left({ }^{\circ} \mathrm{C}\right)$} & \multicolumn{3}{|c|}{$\mathrm{P}$ value } \\
\hline & $<39.1$ & $\geq 39.1$ & Temp. & Prot. & Interaction \\
\hline \multicolumn{6}{|l|}{ Synchronized cows $^{1}$} \\
\hline $\mathrm{GnRH}$ & $88.1(355 / 402)$ & $83.3(304 / 361)$ & 0.09 & 0.93 & 0.34 \\
\hline 2CIDR & $86.2(359 / 415)$ & $84.8(298 / 348)$ & & & \\
\hline \multicolumn{6}{|l|}{ P/AI 32 days for all cows ${ }^{2}$} \\
\hline $\mathrm{GnRH}$ & $39.7(162 / 402)$ & $26.2(98 / 361)$ & $<0.01$ & 0.64 & 0.42 \\
\hline 2CIDR & $38.9(164 / 415)$ & $29.3(105 / 348)$ & & & \\
\hline \multicolumn{6}{|l|}{$\mathrm{P} / \mathrm{AI} 60$ days for all cows ${ }^{2}$} \\
\hline GnRH & $34.0(138 / 402)$ & $22.0(81 / 361)$ & $<0.01$ & 0.91 & 0.79 \\
\hline 2CIDR & $33.6(141 / 415)$ & $22.9(81 / 348)$ & & & \\
\hline \multicolumn{6}{|l|}{$\begin{array}{l}\text { P/AI } 60 \text { days for synchronized } \\
\text { cows }^{3}\end{array}$} \\
\hline GnRH & $38.9(138 / 355)$ & $26.6(81 / 304)$ & $<0.01$ & 0.86 & 0.98 \\
\hline 2CIDR & $39.3(141 / 359)$ & $27.2(81 / 298)$ & & & \\
\hline \multicolumn{6}{|l|}{ Pregnancy loss (32-60 days) $)^{3}$} \\
\hline $\mathrm{GnRH}$ & $14.8(24 / 162)$ & $17.4(17 / 98)$ & 0.09 & 0.48 & 0.34 \\
\hline 2CIDR & $14.0(23 / 164)$ & $22.9(24 / 105)$ & & & \\
\hline
\end{tabular}

*Least square means (n./n.); ${ }^{1}$ Based on presence of CL on day 7, as determined by ultrasound; ${ }^{2}$ Includes all inseminated cows; ${ }^{3}$ Includes only cows that ovulated to ECP (visible CL on day 7 after FTAI). From Pereira et al. (2017b).

\section{Physiology III. Inducing complete regression of CL and low P4 near TAI}

Low $\mathrm{P} 4$ concentrations near the time of $\mathrm{AI}$ is essential for optimal fertility in both GnRH-based (Souza et al., 2005; Brusveen et al., 2009; Martins et al., 2011; Wiltbank et al., 2015) and E2/P4-based (Pereira et al., 2013b; Monteiro et al., 2015) protocols. Various methods have been used to ensure lower P4 near FTAI, including performing treatments with PGF prior to removal of the intravaginal $\mathrm{P} 4$ implant in E2/P4-based TAI programs (Meneghetti et al., 2009; Peres et al., 2009; Pereira et al., 2013b) and treatment with a second PGF, generally $24 \mathrm{~h}$ after the first PGF treatment (Brusveen et al., 2009; Pereira et al., 2015; Wiltbank et al., 2015; Melo et al., 2016). Earlier treatment with PGF should allow more time for CL regression and subsequent reductions in circulating $\mathrm{P} 4$ that could be critical for fertility in cows with a $\mathrm{CL}$ during an E2/P4-based program.

An experiment (Pereira et al., 2013b) investigated P4 concentrations and fertility comparing treatment with PGF at two times in an E2/P4-based FTAI and FTET program in lactating dairy cows. A total of 1,058 lactating Holstein cows, primiparous $(\mathrm{n}=$ $371)$ and multiparous $(\mathrm{n}=687)$, yielding $34.1 \pm 10.4 \mathrm{~kg}$ of milk/d were randomly assigned to receive treatment with PGF on either day-3 or day-2 of the following protocol: day-10: $2 \mathrm{mg}$ EB+CIDR; day-2 CIDR removal + $1.0 \mathrm{mg}$ ECP; day 0 - FTAI or day 7 - FTET. Only cows with a CL on day 7 received an embryo and all cows received GnRH at time of FTET. Pregnancy diagnoses were performed at 28 and 60 days. Fertility (P/AI or $\mathrm{P} / \mathrm{ET}$ ) was affected by breeding technique (AI $v s$. ET) and time of PGF treatment (day-3 vs. day-2), for FTAI (32.9\% [238] vs. 20.6\% [168]) and FTET (47\% [243] vs. 40.7\% [244]) at 28 days, and 60 days for FTAI (30\% [238] vs. 19.2\% [168]) and FTET cows (37.9\% [243] vs. 33.5\% [244]). Circulating P4 on day 0 altered fertility in FTAI with greater $\mathrm{P} / \mathrm{AI}$ in cows with $\mathrm{P} 4<0.1$ $\mathrm{ng} / \mathrm{ml}$ compared to cows with $\mathrm{P} 4 \geq 0.1 \mathrm{ng} / \mathrm{ml}$, and in FTET with greater P/ET in cows with $\mathrm{P} 4<0.22 \mathrm{ng} / \mathrm{ml}$ compared to cows with $\mathrm{P} 4 \geq 0.22 \mathrm{ng} / \mathrm{ml}$ (Table 3 ). Treatment with PGF at day-3 increased percentage of cows with $\mathrm{P} 4<0.1 \mathrm{ng} / \mathrm{ml}$ on day 0 (39.4 vs. 23.2\%). Reducing the interval between PGF and FTAI from 72 to $48 \mathrm{~h}$ in dairy cows dramatically reduced fertility in cows bred by FTAI and had a subtle negative effect in cows that received FTET. Earlier PGF treatment benefits were most likely mediated through improvements in gamete transport, fertilization, or early embryo development, with other effects of earlier PGF manifest after ET on day 7.

It is critical that FTAI programs have low P4 concentrations near FTAI. This can be done in various ways: increasing the dose of PGF, when cloprostenol was used (Giordano et al., 2013), increasing number of PGF treatments (Pereira et al., 2015; Wiltbank et al., 2015), particularly in programs with GnRH at beginning of protocol, and an increased interval from PGF to FTAI (Pereira et al., 2013b) to allow sufficient time for circulating $\mathrm{P} 4$ to reach low concentrations. 
Table 3. Effects of P4 concentrations on day 0 (at AI or 7 days before ET) at day 60 pregnancy diagnosis in lactating dairy cows after FTAI or FTET.

\begin{tabular}{lcccc}
\hline & \multicolumn{3}{c}{ Progesterone $(\mathrm{ng} / \mathrm{ml})$ on day 10} & P-value \\
\cline { 2 - 4 } Item $^{1}$ & $\leq 0.09$ & $0.10-0.21$ & $\geq 0.22$ & - \\
TAI P/AI at Day 60 & & & \\
PGF day-3 & $39.4(36 / 85)$ & $27.5(8 / 26)$ & $14.6(4 / 22)$ & - \\
PGF day-2 & $23.2(15 / 54)$ & $15.1(8 / 45)$ & $21.4(16 / 67)^{\mathrm{y}}$ & 0.05 \\
Combined & $34.1(51 / 139)^{\mathrm{ax}}$ & $20.2(16 / 71)^{\mathrm{b}}$ & & - \\
TET P/ET at day 60 & & & $25.3(12 / 49)$ & - \\
PGF day-3 & $46.8(37 / 77)$ & $44.2(23 / 52)$ & $20.5(9 / 50)$ & - \\
PGF day-2 & $40.0(24 / 58)$ & $46.0(33 / 73)$ & $22.9(21 / 99)^{\mathrm{b}}$ & 0.0006 \\
Combined $^{2}$ & $43.8(61 / 135)^{\mathrm{a}}$ & $45.3(55 / 125)^{\mathrm{a}}$ & & \\
\hline
\end{tabular}

${ }^{1}$ Each value includes least-squares means \% (no./no.); ${ }^{2}$ Combined values of treatments to determine the effect of P4 at day 0 on $\mathrm{P} / \mathrm{AI}$ or $\mathrm{P} / \mathrm{ET}$; a, b Within a row $=\mathrm{P}<0.05 ; \mathrm{x}$, $\mathrm{y}$ Within row $=\mathrm{P}>0.05$ and $\mathrm{P} \leq 0.01$. From Pereira et al. (2013b).

\section{Physiology IV: Synchronizing time of ovulation and optimizing fertility to TAI}

Serum E2 concentrations at FTAI were positively correlated with ovulatory follicle diameter (Vasconcelos et al., 2001; Perry et al., 2005). Furthermore, cows ovulating smaller follicles following GnRH treatment were more likely to have reproductive failure (Perry et al., 2005; Pereira et al., 2013a; Vasconcelos et al., 2013). There is likely an interaction among preovulatory follicle diameter, and optimal hormonal environment (manifested by expression of estrus) and establishment and maintenance of pregnancy (Jinks et al., 2013; Perry et al., 2014).

Studies comparing induction of ovulation using GnRH vs. ECP (Souza et al., 2009) or ECP vs. EB (Melo et al., 2016) were done in Brazil. All of these ovulation-inducing hormones yielded similar fertility. Therefore, despite differences in interval from treatment to ovulation, they were similarly effective in synchronizing ovulation and produced similar fertility.

In lactating dairy cows synchronized with E2/P4 protocols that used ECP for induction of ovulation, estrus expression dramatically affected fertility. A large study (Pereira et al., 2016) evaluated expression of estrus and fertility in FTAI $(n=5,430)$ or FTET $(\mathrm{n}=2,003)$ programs. Ovarian ultrasonography (US) was performed on day0 (time of AI) and day 7 to determine ovulatory follicle diameter and ovulation. Only cows with a visible CL on day 7 were used. At CIDR removal, all cows received a tailhead device for detection of estrus and were considered in estrus when the paint of the device was completely removed by day 0 . Circulating P4 concentrations were evaluated on day 7. At pregnancy diagnosis on day 32, cows with expression of estrus had increased $(\mathrm{P}<0.01) \mathrm{P} / \mathrm{AI}$ (no estrus $=25.5 \%[222 / 846]$ $v s$. estrus $=38.9 \%[1785 / 4584])$ and $\mathrm{P} / \mathrm{ET}$ (no estrus $=$ $32.7 \%[193 / 606]$ vs. estrus $=46.2 \%$ [645/1397]). Similarly, at pregnancy diagnosis on day 60, expression of estrus increased $(\mathrm{P}<0.01) \mathrm{P} / \mathrm{AI}$ (no estrus $=20.1 \%[179 / 846] v s$. estrus $=33.3 \%[1530 / 4584])$ and $\mathrm{P} / \mathrm{ET}$ (no estrus $=25.1 \%[150 / 606] v s$. estrus $=37.5 \%$ $[525 / 1397])$. Pregnancy loss was lower $(P=0.01)$ in cows that expressed estrus in FTAI (no estrus $=20.1 \%$ $[43 / 222] v s$. estrus $=14.4 \%[255 / 1785])$ and FTET (no estrus $=22.7 \%[43 / 193] v s$. estrus $=18.6 \%[120 / 645])$ compared to cows with no estrus. Independent of expression of estrus, P/AI was reduced in cows ovulating either too small or too large of follicles (Quadratic effect; $\mathrm{P}<0.01$; Fig. 3$)$. There was no effect $(\mathrm{P}=0.40)$ of ovulatory follicle diameter on $\mathrm{P} / \mathrm{ET}$ in cows that expressed estrus; however, cows that did not express estrus tended to have lower $(\mathrm{P}=0.08) \mathrm{P} / \mathrm{ET}$ if they ovulated larger follicles. In cows detected in estrus, follicle diameter did not affect pregnancy loss (AI: P = 0.46; ET: $\mathrm{P}=0.45)$, but cows not detected in estrus and ovulating larger follicles tended to have greater pregnancy loss after FTAI $(\mathrm{P}=0.13)$ and had greater pregnancy loss after FTET ( $\mathrm{P}=0.05$; Fig. 4$)$. There was a positive effect of day 7 circulating $\mathrm{P} 4$ concentrations on P/AI $(\mathrm{P}<0.02)$, independent of estrus (Fig. 5). In contrast, there was no effect $(\mathrm{P}>0.5)$ of circulating $\mathrm{P} 4$ concentration on day 7 on $\mathrm{P} / \mathrm{ET}$. Thus, expression of estrus during protocols for FTAI or FTET was associated with an increase in fertility and reduction in pregnancy loss. During FTAI programs, optimizing follicle diameter and increasing circulating P4 on day 7 after AI were also associated with increased fertility, independent of expression of estrus. However, in cows with FTET, the association of fertility with either ovulatory follicle diameter or P4 on day 7 was less dramatic and seemed to be related to whether cows expressed estrus. 


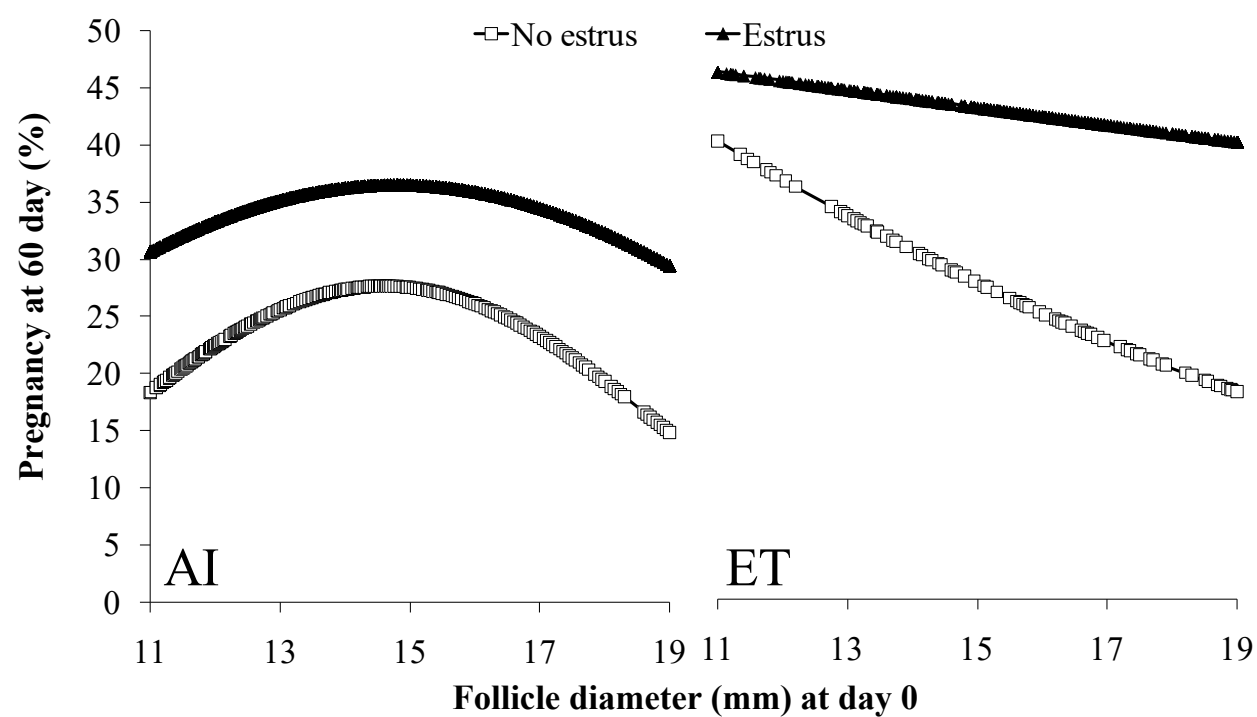

Figure 3. Effects of follicle diameter on day 0 on P/AI (AI) or P/ET (ET) at day 60 in cows that did or did not display estrus. $\mathrm{P} / \mathrm{AI}$ : No Estrus $\mathrm{P}<0.01$; Estrus $\mathrm{P}<0.01$. $\mathrm{P} / \mathrm{ET}$ : No Estrus $\mathrm{P}=0.08$; Estrus $\mathrm{P}=0.40$. From Pereira et al. (2016).

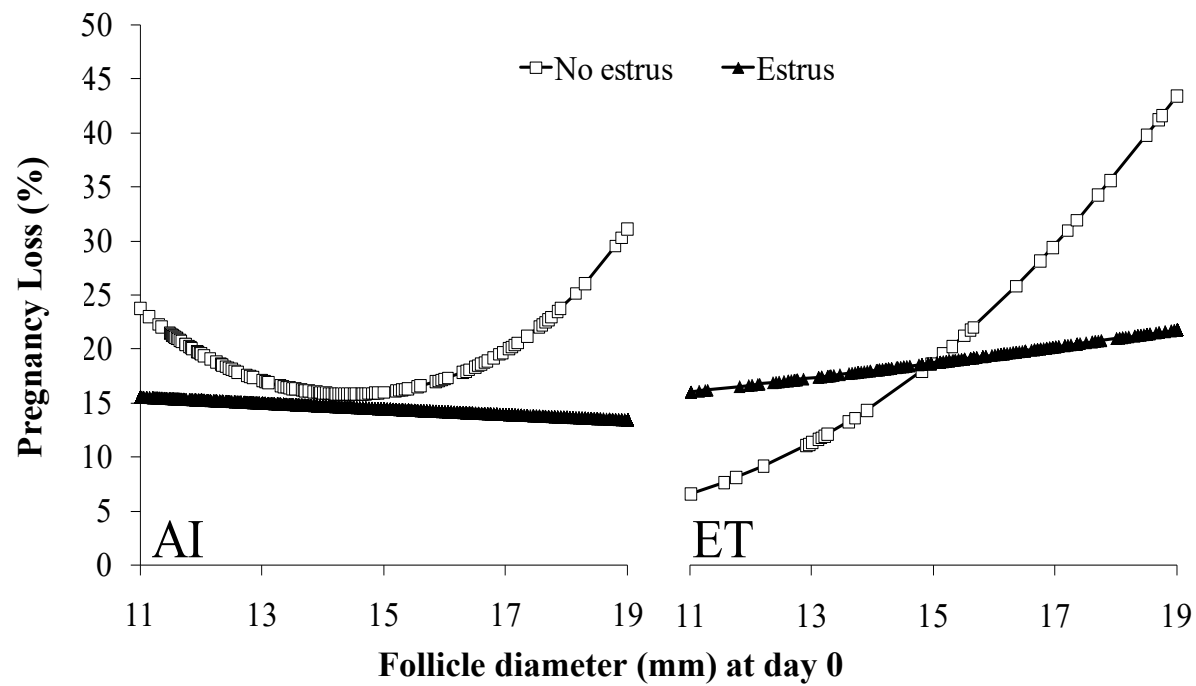

Figure 4. Effects of follicle diameter on day 0 on pregnancy losses (after AI or ET) between day 32 and day 60 in cows that did or did not display estrus or did not display estrus AI: No Estrus, P. 0.13; Estrus, P = 0.46. ET: No Estrus, $\mathrm{P}=0.05$; Estrus $\mathrm{P}=0.45$. From Pereira et al. (2016).

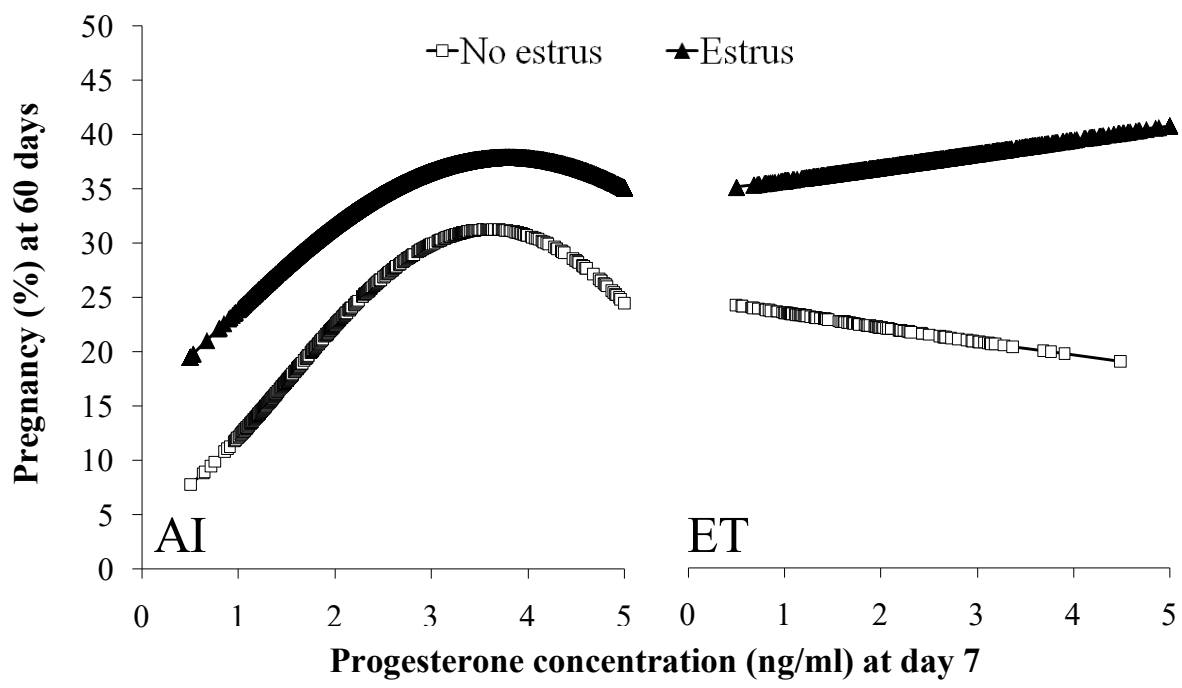

Figure 5. Effects of $\mathrm{P} 4$ concentration on day 7 on $\mathrm{P} / \mathrm{AI}$ or $\mathrm{P} / \mathrm{ET}$ at day 60 in cows that did or did not display estrus. AI: No Estrus, $\mathrm{P}=0.02$; Estrus, $\mathrm{P}=0.01$. ET: No Estrus, $\mathrm{P}=0.76$; Estrus $\mathrm{P}=0.52$. From Pereira et al. (2016). 


\section{Direct comparison of GnRH vs. E2/P4-based TAI programs}

As discussed above, FTAI programs based on GnRH have a somewhat different physiology than E2/P4-based FTAI programs, despite similar physiologic and practical goals. One experiment (Pereira et al., 2013a) was designed to directly compare a GnRH-based to an E2/P4-based protocol for estrous cycle synchronization and FTAI. For this experiment, a 5 days GnRH protocol was compared to the standard E2/P4-based program, since both are designed for synchronization of ovulation and a reduction in the interval from follicular emergence to ovulation in cows with a synchronized follicular wave. A total of 1,190 lactating Holstein cows, primiparous $(\mathrm{n}=685)$ and multiparous $(\mathrm{n}=505)$, yielding $26.5 \pm 0.30 \mathrm{~kg}$ of milk/day at $177 \pm 5.02$ DIM were randomly assigned to one of the following programs: 5-days Cosynch protocol (day-8: CIDR + GnRH, day-3: CIDR removal + PGF, day-2: PGF, day 0: FTAI+GnRH); or E2/P4 protocol (day-10: CIDR + EB, day-3: PGF, day-2: CIDR removal + ECP, day 0: FTAI). Rectal temperature and circulating $\mathrm{P} 4$ concentration were measured on the day-3, $-2,0$ (FTAI) and day 7 . The estrous cycle was considered synchronized when P4 was $1.0 \mathrm{ng} / \mathrm{m} 1$ on day 7 in cow that had previously undergone luteolysis (P4 $\leq 0.4 \mathrm{ng} / \mathrm{ml}$ on day 0$)$. To evaluate effects of heat stress, cows were classified by number of heat stress events, either 0,1 , or $2+$ measurements of elevated body temperature $\left(239.1^{\circ} \mathrm{C}\right)$. Pregnancy success $(\mathrm{P} / \mathrm{AI})$ was determined at 32 and 60 days after FTAI. Cows in the 5days Cosynch protocol had increased $(\mathrm{P}<0.01)$ circulating P4 concentrations at PGF treatment $(2.66 \pm$ 0.13 vs. $1.66 \pm 0.13 \mathrm{ng} / \mathrm{ml}$ ). Cows in the $\mathrm{E} 2 / \mathrm{P} 4$ protocol were more likely $(\mathrm{P}<0.01)$ to be detected in estrus (62.8 vs. 43.4\%) compared to cows in a 5-days Cosynch, and expression of estrus improved $(\mathrm{P}<0.01)$ $\mathrm{P} / \mathrm{AI}$ in both treatments. Cows in the 5-days Cosynch protocol had greater $(\mathrm{P}=0.02)$ percentage of synchronized cycles $(78.2 \%)$, compared to cows in the $\mathrm{E} 2 / \mathrm{P} 4$ protocol $(70.7 \%)$. On day 60 , the E2/P4 protocol tended ( $\mathrm{P}=0.07)$ to improve $\mathrm{P} / \mathrm{AI}(20.7$ vs. $16.7 \%)$ and reduced $(\mathrm{P}=0.05)$ pregnancy loss from 32 to 60 days (11.0 vs. 19.6\%), compared to 5-days Cosynch protocol. In cows with a synchronized cycle, the E2/P4 protocol had greater $(\mathrm{P}=0.03) \mathrm{P} / \mathrm{AI}(25.6 v s .17 .7 \%)$ on day 60 and lower pregnancy loss $(\mathrm{P}=0.01)$ from day 32 to day 60 (6.7 vs. 21.7\%) compared to cows in the 5-days Cosynch protocol. Follicle diameter affected $(\mathrm{P}=0.04)$ pregnancy loss from 32 to 60 days only in cows in the 5-days Cosynch protocol, with smaller follicles resulting in greater pregnancy loss (Fig. 6). P/AI at day 60 was different $(\mathrm{P}=0.01)$ between protocols in the cows with two or more measurements of heat stress (5-days Cosynch $=12.2 \% v s . \mathrm{E} 2 / \mathrm{P} 4=22.8 \%)$, but not in cows without or with only one heat stress measurement $(\mathrm{P}=0.6)$. In conclusion, the 5-days Cosynch protocol apparently produced better estrous cycle synchronization than the E2/P4 protocol but did not improve P/AI. The potential explanation for these results is that increased E2 concentrations during the periovulatory period can improve pregnancy success and pregnancy maintenance; furthermore, this effect appeared to be greatest in heat-stressed cows, apparently with lower circulating E2 concentrations.

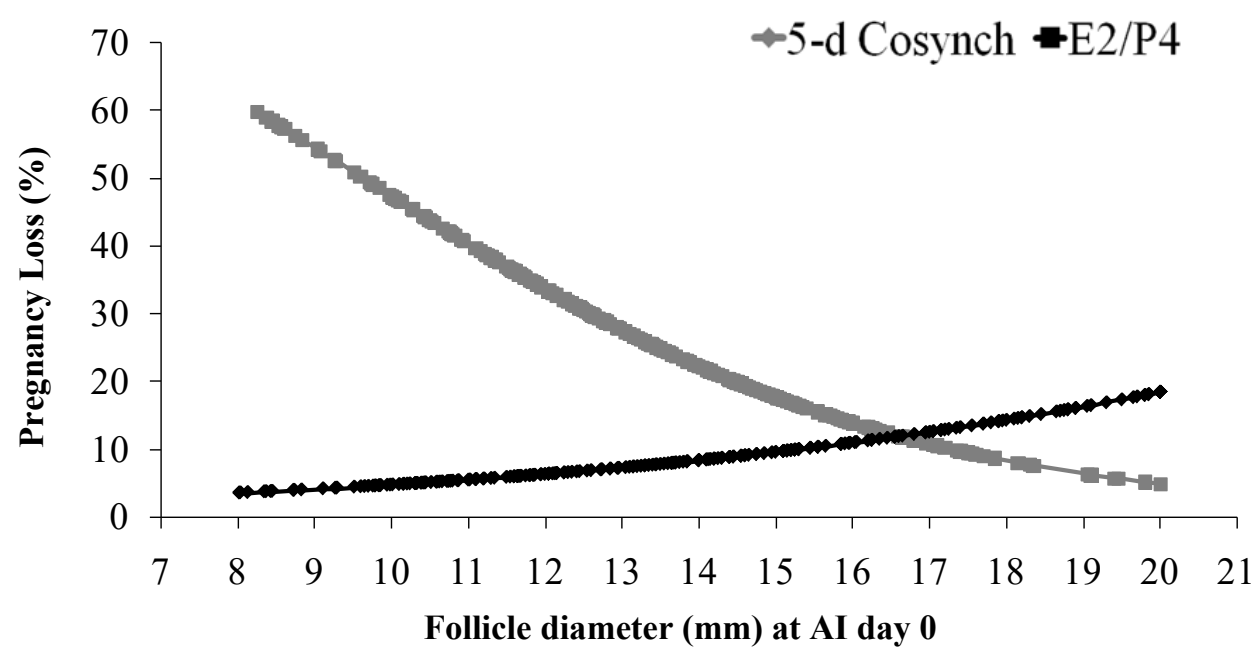

Figure 6. Effect of follicle diameter at AI on pregnancy loss between day 32 and day 60 in cows subjected to either $\mathrm{E} 2 / \mathrm{P} 4$ or 5-days Cosynch protocols and had their cycle synchronized ( $\mathrm{P} 4 \leq 0.4 \mathrm{ng} / \mathrm{ml}$ at day 0 and $\mathrm{P} \geq 1.0 \mathrm{ng} / \mathrm{ml}$ at day 7) 5-days Cosynch $(\mathrm{P}=0.04): \mathrm{y}=-0.276 \mathrm{x}+2.4648 ; \mathrm{E} 2 / \mathrm{P} 4(P=0.32): \mathrm{y}=0.01063 \mathrm{x}-3.8241$. From Pereira et al. (2013a).

\section{Discussion}

Research on FTAI in lactating dairy cows in Brazil during the last 20 years has highlighted some key physiological principles that are important for improving fertility to FTAI and FTET programs. First, slight elevations in P4 near AI can reduce fertility. This was illustrated by the finding that an earlier treatment with PGF (i.e. 1 day prior to removal of intravaginal P4 implant; day-3 vs. day-2) allowed greater time for regression of the $\mathrm{CL}$, lower $\mathrm{P} 4$ at CIDR removal and at FTAI, and greater fertility. Greater P4 concentrations at FTAI $(>0.1 \mathrm{ng} / \mathrm{ml})$ were clearly associated with reduced fertility in FTAI cows. In ET cows, fertility 
improvement after earlier regression of the CL was less dramatic than after AI, with no reduction in fertility to FTET until circulating P4 concentrations near ovulation reached $>0.21 \mathrm{ng} / \mathrm{ml}$. Thus, it appears that there is a dramatic effect on fertility of earlier PGF treatment that was likely mediated through more complete CL regression which likely improved gamete transport, fertilization, or early embryo development with more subtle effects of earlier PGF treatment in FTET programs likely mediated through changes in the uterine or hormonal environment after day 7 (time of ET).

Second, the absence of a CL and low circulating $\mathrm{P} 4$ at initiation of a protocol also appears to be a problem for dairy herds in Brazil. Two methods for increasing P4 during E2/P4-based FTAI protocols in lactating dairy cows that were discussed in this manuscript are: 1) combine $\mathrm{GnRH}$ with the $\mathrm{EB}$ at the beginning of the protocol (Pereira et al. 2015) or 2) utilize two intravaginal $\mathrm{P} 4$ implants rather than only one implant during the protocol (Pereira et al. 2017a). Both of these strategies have resulted in greater fertility in lactating cows that do not have a CL at the start of the protocol.

Third, follicle diameter was linked to P/AI in several studies. Ovulation of an undersized follicle was generally associated with reduced $\mathrm{P} / \mathrm{AI}$, reduced $\mathrm{E} 2$ concentrations, an increased incidence of short luteal phases (Vasconcelos et al., 2001), and sometimes increased pregnancy loss (Perry et al., 2005). In contrast, ovulation of an oversized follicle can also be associated with reduced $\mathrm{P} / \mathrm{AI}$, perhaps due to ovulation of a persistent dominant follicle (Townson et al., 2002, Bleach et al., 2004, Cerri et al., 2009). In a number of these studies, follicle size in cows that did not display estrus was related to $\mathrm{P} / \mathrm{AI}$ and $\mathrm{P} / \mathrm{ET}$ at either the 32 or 60 days pregnancy diagnoses.

Fourth, the critical effect of estrus as a predictor of fertility in E2/P4-based FTAI programs has been clearly illustrated. Expression of estrus requires low circulating P4 concentrations plus increased circulating E2 of a sufficient magnitude and duration (Allrich, 1994). We measured P4 near the time of AI in a subset of cows $(\mathrm{n}=2372$; Pereira et al., 2016); there was a difference $(\mathrm{P}<0.01)$ in circulating $\mathrm{P} 4$ in cows that expressed $(0.15 \pm 0.03 \mathrm{ng} / \mathrm{ml})$ versus cows that did not express estrus $(0.19 \pm 0.03 \mathrm{ng} / \mathrm{ml})$. Although relatively small in magnitude, this may account for a lack of behavioral estrus in some cows. In cows that had their cycle synchronized, expression of estrus was associated with an increase in P/AI and P/ET at 32 and 60 days and reduced pregnancy losses between 32 and 60 days of pregnancy. Similar results were reported in previous studies in dairy cows using various FTAI protocols. For example, using Heatsynch protocols, cows that displayed estrus after the ECP had greater P/AI (42.5\% [306]) than cows not in estrus (21.1\% [71]) at FTAI (Cerri et al., 2004). Therefore, expression of estrus was a predictor of fertility and pregnancy loss in both FTAI and FTET programs.

Finally, one of the largest problems for reproductive management programs of lactating dairy cows in Brazil is the reduced $\mathrm{P} / \mathrm{AI}$ that occurs due to heat stress (Vasconcelos et al., 2006, 2011a, b, c). Plasma E2 concentrations are reduced by heat stress in dairy cows (Wolfenson et al., 1995, 1997; Wilson et al., 1998) and E2 supplementation may improve fertilization, subsequent embryonic development, and pregnancy maintenance. Pregnancy loss was reduced or tended to be reduced in cows with expression of estrus (Pereira et al., 2013a, 2016), those with greater circulating E2 concentrations near FTAI (Souza et al., 2007, 2011; Hillegass et al., 2008), and cows that had increased length of proestrus (Ribeiro et al., 2012). In these studies, cows detected in estrus had decreased pregnancy losses, irrespective of preovulatory follicle diameter.

In addition, the $\mathrm{P} 4$ concentration at day 7 after AI was associated with P/AI (quadratic effect), independent of estrus expression, but was not related to P/ET (Demetrio et al., 2007). Higher P4 concentrations may be indicative of a better CL, due to enhanced follicle and oocyte health or physiological function.

\section{Conclusions}

Based on field experiences and the results reported in these studies, heat stress is one of the major factors that reduce fertility in dairy cows during FTAI protocols in Brazil as demonstated by cows with an increased body temperature $39.1^{\circ} \mathrm{C}$ ) having large reductions in $\mathrm{P} / \mathrm{AI}$. In addition, fertility can be substantially altered by the hormonal concentrations during the protocol, when circulating $\mathrm{P} 4$ needs to be elevated, and near the end of the protocol, when P4 needs to be basal and circulating E2 needs to be elevated. Evidence was provided that increasing circulating P4 during preovulatory follicle development improved P/AI, particularly in cows with low $\mathrm{P} 4$ at the start of the protocol. This was done by inducing ovulation (with exogenous $\mathrm{GnRH}$ ) at the beginning of an E2/P4-based protocol, or by inserting a second CIDR at the beginning of the protocol. Near the end of the protocol, treatment with PGF one day before removal of the intravaginal P4 implant, reduced circulating P4 near FTAI and increased fertility following FTAI and FTET. It also appears that increasing E2 concentrations prior to AI can improve pregnancy success and pregnancy maintenance as evidenced by the dramatic effects of expression of estrus on $\mathrm{P} / \mathrm{AI}, \mathrm{P} / \mathrm{ET}$, and pregnancy loss. In addition, increasing the length of the protocol for FTAI increased the percentage of cows detected in estrus and decreased pregnancy loss. Following FTAI programs, increasing circulating P4 7 days after AI was associated with increased fertility, independent of expression of estrus. In cows with FTET, the association of fertility with either preovulatory follicle diameter or circulating P4 concentrations at time of ET (day 7) was less dramatic and seemed to be related to whether cows expressed estrus. Thus, during the last two decades FTAI protocols have been improved and are likely to continue to be improved for dairy cows in Brazil by focusing on increasing synchronization of follicular waves, optimizing hormonal concentrations during specific stages of the protocol, and by improving 
percentage of cows ovulating in a synchronized time period at the end of the protocol.

\section{Acknowledgments}

We thank Brazilian granting agencies FAPESP, CAPES and CNPq for research grant support; Zoetis for pharmaceutical products; students and staff at São Paulo State University for technical support; owners and staff of collaborating dairies for use of cattle and facilities.

\section{References}

Allrich RD. 1994. Endocrine and neural control of estrus in dairy cows. J Dairy Sci, 77:2738-2744.

Baruselli PS, Sales JNS, Sala RV, Viera LM, Sá Filho MF. 2012. History, evolution and perspectives of timed artificial insemination programs in Brazil. Anim Reprod, 9:139-152.

Binelli M, Sartori R, Vasconcelos JLM, Monteiro Jr PLJ, Pereira MHC, Ramos RS. 2014. Evolution in fixed-time: from synchronization of ovulation to improved fertility. In: 2014 Proceedings 9th International Ruminant Reproduction Symposium, Obihiro City, Hokkaido, Japan. Burton-On-Trent, UK: Context. pp. 493-506.

Bisinotto RS, Ribeiro ES, Martins LT, Marsola RS, Greco LF, Favoreto MG, Risco CA, Thatcher WW, Santos JEP. 2010. Effect of interval between induction of ovulation and artificial insemination (AI) and supplemental progesterone for resynchronization on fertility of dairy cows subjected to a 5 -d timed AI program. J Dairy Sci, 93:5798-5808.

Bleach EC, Glencross RG, Knight PG. 2004. Association between ovarian follicle development and pregnancy rates in dairy cows undergoing spontaneous oestrous cycles. Reproduction, 127:621-629.

Brusveen DJ, Souza AH, Wiltbank MC. 2009. Effects of additional prostaglandin F2 $\alpha$ and estradiol-17 $\beta$ during Ovsynch in lactating dairy cows. J. Dairy Sci, 92:1412-1422.

Buhi WC. 2002. Characterization and biological roles of oviduct-specific, oestrogen-dependent glycoprotein. Reproduction, 123:355-362.

Cerri RLA, Santos JEP, Juchem SO, Galvao KN, Chebel RC. 2004. Timed artificial insemination with estradiol cypionate or insemination at estrus in highproducing dairy cows. J Dairy Sci, 87:3704-3715.

Cerri RLA, Rutigliano HM, Chebel RC, Santos JEP 2009. Period of dominance of the ovulatory follicle influences embryo quality in lactating dairy cows. Reproduction, 137:813-823.

Demetrio DG, Santos RM, Demetrio CG, Vasconcelos JLM. 2007. Factors affecting conception rates following artificial insemination or embryo transfer in lactating Holstein cows. $J$ Dairy $S c i$, 90:5073-5082.

Giordano JO, Wiltbank MC, Fricke PM, Bas S, Pawlisch R, Guenther JN, Nascimento AB. 2013. Effect of increasing GnRH and PGF2alpha dose during Double-Ovsynch on ovulatory response, luteal regression, and fertility of lactating dairy cows.
Theriogenology, 80:773-783.

Hillegass J, Lima FS, Sá Filho MF, Santos JEP. 2008. Effect of time of artificial insemination and supplemental estradiol on reproduction of lactating dairy cows. J Dairy Sci, 91:4226-4237.

Jinks EM, Smith MF, Atkins JA, Pohler KG, Perry GA, Macneil MD, Roberts AJ, Waterman RC, Alexander LJ, Geary TW. 2013. Preovulatory estradiol and the establishment and maintenance of pregnancy in suckled beef cows. J Anim Sci, 91:11761185.

Martins JPN, Policelli RK, Neuder LM, Raphael W, Pursley JR. 2011. Effects of cloprostenol sodium at final prostaglandin $F 2 \alpha$ of Ovsynch on complete luteolysis and pregnancy per artificial insemination in lactating dairy cows. J Dairy Sci, 94:2815-2824.

Melo LF, Monteiro PLJ, Surjus RS, Drum JN, Wiltbank MC, Sartori R. 2016. Progesterone-based fixed-time artificial insemination protocols for dairy cows: gonadotropin-releasing hormone versus estradiol benzoate at initiation and estradiol cypionate versus estradiol benzoate at the end. J Dairy Sci, 99:92279237.

Meneghetti M, Sa Filho OG, Peres RF, Lamb GC, Vasconcelos JL. 2009. Fixed-time artificial insemination with estradiol and progesterone for Bos indicus cows I: basis for development of protocols. Theriogenology, 72:179-189.

Miller BG, Moore NW, Murphy L, Stone GM. 1977. Early pregnancy in the ewe: effects of oestradiol and progesterone on uterine metabolism and on embryo survival. Aust J Biol Sci, 30:279-288.

Monteiro PL, Jr, Borsato M, Silva FL, Prata AB, Wiltbank MC, Sartori R. 2015. Increasing estradiol benzoate, pretreatment with gonadotropin-releasing hormone, and impediments for successful estradiolbased fixed-time artificial insemination protocols in dairy cattle. J Dairy Sci, 98:3826-3839.

Pereira MHC, Rodrigues ADP, Martins T, Oliveira WVC, Silveira PSA, Wiltbank MC, Vasconcelos JLM. 2013a. Timed artificial insemination programs during the summer in lactating dairy cows: comparison of the 5-d Cosynch protocol with an estrogen/progesterone-based protocol. $J$ Dairy Sci, 96:6904-6914

Pereira MHC, Sanches CP, Guida TG, Rodrigues ADP, Aragon FL, Veras MB, Borges PT, Wiltbank MC, Vasconcelos JLM. 2013b. Timing of prostaglandin $\mathrm{F} 2 \alpha$ treatment in an estrogen-based protocol for timed artificial insemination or timed embryo transfer in lactating dairy cows. $J$ Dairy Sci, 96:2837-2846.

Pereira MHC, Rodrigues ADP, De Carvalho RJ, Wiltbank MC, Vasconcelos JLM. 2014. Increasing length of an estradiol and progesterone timed artificial insemination protocol decreases pregnancy losses in lactating dairy cows. J Dairy Sci, 97:1454-1464.

Pereira MHC, Wiltbank MC, Barbosa LFSP, Costa WM, Carvalho MAP, Vasconcelos JLM. 2015. Effect of adding a gonadotropin-releasing-hormone treatment at the beginning and a second prostaglandin F-2 alpha treatment at the end of an estradiol-based protocol for 
timed artificial insemination in lactating dairy cows during cool or hot seasons of the year. J Dairy Sci, 98:947-959.

Pereira MHC, Wiltbank MCVasconcelos JLM. 2016. Expression of estrus improves fertility and decreases pregnancy losses in lactating dairy cows that receive artificial insemination or embryo transfer. $J$ Dairy $S c i$ 99:2237-2247.

Pereira MHC, Sanches CP, Guida TG, Wiltbank MC, Vasconcelos JLM. 2017a. Comparison of fertility following use of one versus two intravaginal progesterone inserts in dairy cows without a CL during a synchronization protocol before timed AI or timed embryo transfer. Theriogenology, 89:72-78.

Pereira MHC, Wiltbank MC, Guida TG, Lopes FR, Vasconcelos JLM. 2017b. Comparison of 2 protocols to increase circulating progesterone concentration before timed artificial insemination in lactating dairy cows with or without elevated body temperature. $J$ Dairy Sci, 100:8455-8470.

Peres RF, Claro I Jr, Sa Filho OG, Nogueira GP, Vasconcelos JLM. 2009. Strategies to improve fertility in Bos indicus postpubertal heifers and nonlactating cows submitted to fixed-time artificial insemination. Theriogenology, 72:681-689.

Perry GA, Smith MF, Lucy MC, Green JA, Parks TE, MacNeil MD, Roberts AJ, Geary TW. 2005. Relationship between follicle size at insemination and pregnancy success. Proc Natl Acad Sci USA, 102:52685273.

Perry GA, Swanson OL, Larimore EL, Perry BL, Djira GD, Cushman RA. 2014. Relationship of follicle size and concentrations of estradiol among cows exhibiting or not exhibiting estrus during a fixed-time AI protocol. Domest Anim Endocrinol, 48:15-20.

Peters MW, Pursley JR. 2003. Timing of final GnRH of the Ovsynch protocol affects ovulatory follicle size, subsequent luteal function, and fertility in dairy cows. Theriogenology, 60:1197-1204.

Pursley JR, Mee MO, Wiltbank MC. 1995. Synchronization of ovulation in dairy cows using PGF2alpha and GnRH. Theriogenology, 44:915-923.

Pursley JR, Kosorok MR, Wiltbank MC. 1997 Reproductive management of lactating dairy cows using synchronization of ovulation. J Dairy Sci, 80:301-306.

Ribeiro ES, Monteiro AP, Lima FS, Ayres H, Bisinotto RS, Favoreto M, Greco LF, Marsola RS, Thatcher WW, Santos JEP. 2012. Effects of presynchronization and length of proestrus on fertility of grazing dairy cows subjected to a 5-day timed artificial insemination protocol. J Dairy Sci, 95:25132522.

Sangsritavong S, Combs DK, Sartori R, Armentano LE, Wiltbank MC. 2002. High feed intake increases liver blood flow and metabolism of progesterone and estradiol-17 beta in dairy cattle. J Dairy Sci, 85:28312842.

Santos JEP, Narciso CD, Rivera F, Thatcher WW, Chebel RC. 2010. Effect of reducing the period of follicle dominance in a timed artificial insemination protocol on reproduction of dairy cows. J Dairy Sci, 93:2976-2988.
Souza AH, Gumen A, Silva EPB, Cunha AP, Guenther JN, Peto CM, Caraviello DZ, Wiltbank MC. 2005. Effect of estradiol-17 beta supplementation before the last GnRH of the Ovsynch protocol in high producing dairy cows. J Dairy Sci, 88:170-170.

Souza AH, Gumen A, Silva EPB, Cunha AP, Guenther JN, Peto CM, Caraviello DZ, Wiltbank MC. 2007. Supplementation with estradiol-17beta before the last gonadotropin-releasing hormone injection of the Ovsynch protocol in lactating dairy cows. J Dairy Sci, 90:4623-4634.

Souza AH, Viechnieski S, Lima FA, Silva FF, Araujo R, Bo GA, Wiltbank MC, Baruselli PS. 2009. Effects of equine chorionic gonadotropin and type of ovulatory stimulus in a timed-AI protocol on reproductive responses in dairy cows. Theriogenology, 72:10-21.

Souza AH, Silva EPB, Cunha AP, Gümen A, Ayres H, Brusveen DJ, Guenther JN, Wiltbank MC. 2011. Ultrasonographic evaluation of endometrial thickness near timed AI as a predictor of fertility in highproducing dairy cows. Theriogenology, 75:722-733.

Thatcher WW, Moreira F, Pancarci SM, Bartolome JA, Santos JE. 2002. Strategies to optimize reproductive efficiency by regulation of ovarian function. Domest Anim Endocrinol, 23:243-254.

Thatcher WW, Santos JE. 2007. Control of ovarian follicular and corpus luteum development for the synchronization of ovulation in cattle. Soc Reprod Fertil Suppl, 64:69-81.

Townson DH, Tsang PC, Butler WR, Frajblat M, Griel LC, Johnson CJ, Milvae RA, Niksic GM, Pate JL. 2002. Relationship of fertility to ovarian follicular waves before breeding in dairy cows. J Anim Sci, 80:1053-1058

Vasconcelos JLM, Silcox RW, Rosa GJM, Pursley JR, Wiltbank MC. 1999. Synchronization rate, size of the ovulatory follicle, and pregnancy rate after synchronization of ovulation beginning on different days of the estrous cycle in lactating dairy cows. Theriogenology, 52:1067-1078.

Vasconcelos JLM, Sartori R, Oliveira HN, Guenther JG, Wiltbank MC. 2001. Reduction in size of the ovulatory follicle reduces subsequent luteal size and pregnancy rate. Theriogenology, 56:307-314.

Vasconcelos JLM, Sangsritavong S, Tsai SJ, Wiltbank MC. 2003. Acute reduction in serum progesterone concentrations after feed intake in dairy cows. Theriogenology, 60:795-807.

Vasconcelos JLM, Demétrio DG, Santos RM, Chiari JR, Rodrigues CA, Sá Filho OG. 2006. Factors potentially affecting fertility of lactating dairy cow recipients. Theriogenology 65:192-200.

Vasconcelos JLM, Cooke RF, Jardina DT, Aragon FL, Veras MB, Soriano S, Sobreira N, Scarpa AB. 2011a. Associations among milk production and rectal temperature on pregnancy maintenance in lactating recipient dairy cows. Anim Reprod Sci, 127:140-147.

Vasconcelos JLM, Jardina DTG, Sá Filho OG, Aragon FL, Veras MB. 2011b. Comparison of progesterone-based protocols with gonadotropinreleasing hormone or estradiol benzoate for timed artificial insemination or embryo transfer in lactating 
dairy cows. Theriogenology, 75:1153-1160.

Vasconcelos JLM, Sá Filho OG, Justolin PL, Morelli P, Aragon FL, Veras MB, Soriano S. 2011c. Effects of postbreeding gonadotropin treatments on conception rates of lactating dairy cows subjected to timed artificial insemination or embryo transfer in a tropical environment. J Dairy Sci, 94:223-234.

Vasconcelos JLM, Pereira MHC, Meneghetti M, Dias CC, Sá Filho OG, Peres RFG, Rodrigues ADP, Wiltbank MC. 2013. Relationships between growth of the preovulatory follicle and gestation success in lactating dairy cows. Anim Reprod, 10:206-214.

Wilson SJ, Kirby CJ, Koenigsfeld AT, Keisler DH, Lucy MC. 1998. Effects of controlled heat stress on ovarian function of dairy cattle. 2. Heifers. J Dairy Sci, 81:2132-2138.

Wiltbank M, Lopez H, Sartori R, Sangsritavong S, Gumen A. 2006. Changes in reproductive physiology of lactating dairy cows due to elevated steroid metabolism. Theriogenology, 65:17-29.

Wiltbank MC, Sartori R, Herlihy MM, Vasconcelos JLM, Nascimento AB, Souza AH, Ayres H, Cunha AP, Keskin A, Guenther JN, Gumen A. 2011a Managing the dominant follicle in lactating dairy cows. Theriogenology, 76:1568-1582.

Wiltbank MC, Souza AH, Carvalho PD, Bender
RW, Nascimento AB. 2011b. Improving fertility to timed artificial insemination by manipulation of circulating progesterone concentrations in lactating dairy cattle. Reprod Fertil Dev, 24:238-243.

Wiltbank MC, Pursley JR. 2014. The cow as an induced ovulator: timed AI after synchronization of ovulation. Theriogenology, 81:170-185.

Wiltbank MC, Souza AH, Carvalho PD, Cunha AP, Giordano JO, Fricke PM, Baez GM, Diskin MG. 2014. Physiological and practical effects of progesterone on reproduction in dairy cattle. Animal, 8:70-81.

Wiltbank MC, Baez GM, Cochrane F, Barletta RV, Trayford CR, Joseph RT. 2015. Effect of a second treatment with prostaglandin F-2 alpha during the Ovsynch protocol on luteolysis and pregnancy in dairy cows. J Dairy Sci, 98:8644-8654.

Wolfenson D, Thatcher WW, Badinga L, Savio JD, Meidan R, Lew BJ, Braw-Tal R, Berman A. 1995. Effect of heat stress on follicular development during the estrous cycle in lactating dairy cattle. Biol Reprod, 52:1106-1113

Wolfenson D, Lew BJ, Thatcher WW, Graber Y, Meidan R. 1997. Seasonal and acute heat stress effects on steroid production by dominant follicles in cows. Anim Reprod Sci, 47:9-19. 